[Transaction ]

\title{
A Cross-National Comparison of the Importance of Apparel Store Attributes for Shopping Values between Korean and Chinese College Students
}

\author{
Nari Park $\cdot$ Young-Sil Jang $\cdot$ Jae-Ok Park \\ Dept. of Clothing \& Textiles, Hanyang University
}

Received May 15, 2009; Revised (August 20, 2009; September 11, 2009); Accepted October 5, 2009

\author{
한국과 중국 대학생들의 쇼핑가치에 따른 의류점포속성 중요도 비교 \\ 박나리 · 장영실 - 박재옥 \\ 한양대학교 생활과학대학 의류학과 \\ 접수일(2009년 5월 15일), 수정일(1차 : 2009년 8월 20일, 완료일 : 2009년 9월 11일), 게재확정일(2009년 10월 5일)
}

\begin{abstract}
This study identifies the apparel shopping value segments of Korean and Chinese college students to examine the differences in the importance of apparel store attributes. Data from 504 questionnaires filled out by college students from Seoul and Beijing were used for statistical analysis. The four segments of apparel shopping values are, hedonic shopping segment, low involvement shopping segment, high involvement shopping segment, and utilitarian shopping segment. In the high involvement shopping segment, Korean respondents considered store atmosphere, convenience, and the services of salespersons to be more important than the other segments. Chinese respondents in both the hedonic shopping segment and high involvement shopping segment considered store atmosphere more important than the other segments. Korean respondents considered store service more important than the Chinese respondents in the hedonic shopping segment, but Chinese respondents were more likely to consider store convenience to be more important than Korean respondents. In the low involvement shopping segment, Korean respondents considered store atmosphere, store services, and the selection of goods more important than Chinese respondents did. In the high involvement shopping segment, Korean respondents considered the services of salespersons to be more important than the Chinese respondents but the Chinese respondents evaluated store convenience as more important than Korean respondents. In the utilitarian shopping segment, Korean respondents were more likely to consider store service, the selection of goods, and services of salespersons more important than Chinese respondents did.
\end{abstract}

Key words: Apparel shopping value, Apparel store attributes, Chinese consumers; 의류쇼핑가치, 의류 점포속성, 중국 소비자

\section{Introduction}

A cross-national understanding of consumer preferences and behavior related to apparel purchase

${ }^{\dagger}$ Corresponding author

E-mail: jaepark@hanyang.ac.kr decisions is needed as global trade and economic interdependence has increased in apparel production and marketing (Forney et al., 1993). An understanding is necessary regarding the extent to which consumers from different nations evaluate services and goods in order to be successful in the global market 
(Hsu \& Burns, 2002). Consumer purchases are influenced by personal values, choices in the market place, product awareness, and concerns present during the decision-making process (Forney et al., 1993). Researchers have agreed that culture influences consumer behavior through values (Schwartz, 1990; Srnka, 2004). Many marketers also recognize the need to understand the unique aspects of each country in order to tailor products and marketing strategies appropriately (Solomon, 2008). To understand consumption in a specific culture, the values can guide the members of that culture to determine and justify individual choices (Smith \& Schwartz, 1997).

China was the fastest growing economy over the last two decades and has played an important role in the global apparel consumer market as well as apparel export sales. From 2000 to 2006, the annual growth of the Chinese apparel industry in terms of output averaged 24\% (China Customs Statistics, 2008). As the international business world increasingly focuses on China as a potential new market, there is a growing body of literature attesting to the cultural heterogeneity across Asia and within China (Shen et al., 2003).

The unique cultural position of China compared with other Asian countries is attributed to dramatic social and political events. Marketers must consider the Chinese cultural uniqueness because consumers are influenced by indigenous factors such as a socialist ideology and the rapid economic development (Anderson \& He, 1998). The Chinese encounter more dramatic differences due to distinctively different value systems and experiences in marketing goods and services (Rosenthal \& Feldman, 1992). The Korean market structure and consumption patterns appear different to the Chinese. Therefore, it is thought that Chinese consumers have a different shopping style or orientation compared to Korean consumers.

The understanding of Chinese consumers for marketing apparel products becomes clear as international firms have begun selling products in China. Because the apparel shopping values of college students are expressed by choosing an apparel store, it is important for retailers to understand what the desires are for Chinese and Korean college students in apparel shopping in order to segment the market based on apparel shopping values (Lee et al., 2002).

Only a limited number of cross-national comparison studies concerning apparel store attributes and shopping values between Koreans and Chinese exist (Hong \& Kim, 2002; Kim \& Kim, 2005; Lee et al., 2002; Park, 2006). This study identified the segments of Korean and Chinese college students according to apparel shopping values in order to examine the differences in the importance of apparel store attributes according to Korean and Chinese segments in order to examine the differences in the importance of apparel store attributes for Koreans and Chinese.

\section{Literature Review}

\section{Apparel Shopping Values}

Examining the values of consumers is another way to understand why consumers vary in individual decision making ability (Blackwell et al., 2006). Values play a central role in cognition because people hold similar values but differ only in the importance they place on them. These values provide a powerful basis of understanding consumer behavior within and across cultures (Burgess \& Steenkamp, 1999).

Shopping values have been classified into two categories (utilitarian value and hedonic value) in several studies (e.g., Babin et al., 1994; Crowley et al., 1992; Hartman \& Samra, 2008). The utilitarian shopping value is characterized in an information-processing framework (Hartman \& Samra, 2008) and plays a role as a means to achieving optimal values and emphasized shopping efficiency (Barbin et al., 1994; Blackwell et al., 2006). In contrast, hedonic shopping values are affected by situational variables such as product type and the shopping environment that are commonly expressed in recreational store browsing (Barbin \& Attaway, 2000; Bloch et al., 1989).

The importance of values for clothing behavior and the evaluation of apparel store attributes have been documented to be related to the nationality of consumers. Korean hedonic apparel shoppers were influenced by selection, fashion, recreational facilities, interior, services, and companions within the store when making purchasing decisions (Hwang, 2001). 
Cha et al. (1999) reported that Korean consumers that were concerned with apparel shopping considered, services, store atmosphere, product selection, convenience, advertising, and product display important, in addition hedonic apparel shoppers considered convenience and advertising to be more important than the others. In the results of the study by Lee et al. (2002) showed that the Chinese who were highly involved in apparel shopping believed the selection of goods, cleanness of the store, and store reputation were more important than those who were slightly involved in apparel shopping. Chang and Ok (2007) reported that Chinese consumers in the fashion-oriented segment evaluated store services, the assortment of clothing, and store convenience to be more important than the utilitarian segment did.

\section{Apparel Store Attributes}

Store attributes are defined in various ways; the brand of a retailer (such as a product) involves both functional attributes and emotional attributes (Peter \& Olson, 2007). Various attributes within the store can influence consumer perception and behavior in that consumers recognize a store through various dimensions (Hirschman \& Krishnan, 1981). Lindquist (1974) defined nine criteria that shape image (product, services, customer characteristics, store facilities, convenience, sales promotions, store atmosphere, policy on adjustments, and consumer satisfaction). Shim and Kotsiopulos (1993) classified apparel store attributes into store personnel, visual image of store, customer service, price, easy access, and brand/fashion. They found that shoppers who were highly involved in clothing tended to place high levels of importance on store attributes, but convenience-oriented shoppers had a tendency to place importance on easy access. Kim and Chen-Yu (2005) classified apparel store attributes into store-related attributes, product-related attributes, community/convenience-related attributes, and reputation-related attributes. They reported that special sale prices and product variety (in terms of productrelated attributes) were considered more important by economy-conscious participants than by brand-conscious participants. Hong and Koh (2002) classified apparel store attributes into price/variety, customer services/convenience, discount policy, and apparel style. They reported that well-educated Korean women in the budget-oriented segment evaluated customer services and convenience to be more important than less-educated women did.

In the results from the study by Lee et al. (2002), the depth and extent of the assortment, store popularity, store cleanness, purchasing experience, and price were important determinants of store choice to Chinese female college students who were highly involved in apparel shopping. In the study by Chang and Ok (2007) on Chinese college students, location, and services were the most considerable criteria in terms of store attributes, followed by assortment, fashion, and convenient facilities. Hong and Kim (2002) reported that Chinese female consumers considered display windows the most important, followed by brand popularity, and salesperson assistance.

\section{Methods}

\section{Research Purpose}

This study identifies the segments of Korean and Chinese college students according to apparel shopping values, examines the differences in importance of apparel store attributes according to Korean and Chinese segments, and examines the differences in the importance of apparel store attributes according to Korean and Chinese segments.

\section{Measurements}

Scales measuring apparel shopping values (14 statements) were developed based on prior research (Barbin et al., 1994; Crowley et al., 1992; Shim \& Kotsiopulos, 1992). Scales measuring apparel store attributes (14 statements) were also developed based on prior research (Hirschman \& Krishnan, 1981; Hong \& Koh, 2002; Kim \& Chen-Yu, 2005; Shim \& Kotsiopulos, 1993). All statements were measured on a five-point Likert type scale.

The questionnaire was first developed in Korean and was translated into Chinese after a pilot test. The 
back-translation method was used to ensure the correctness of the translation. Two Korean and Chinese bilingual graduate students translated the Chinese questionnaire back into Korean. The original Korean questionnaire and the back-translated Korean version were compared in this study to ensure that the meaning of each question was consistent.

\section{Data Collection and Sample Characteristics}

College students from Seoul and Beijing participated in the study from October to November 2008. Data from 504 questionnaires (266 from Korea and 238 from China) were used for the statistical analysis. Cronbach's alpha coefficient, cluster analysis, chisquare analysis, $t$-test, ANOVA, and Duncan test using SPSS 12.0 were conducted for the factor analysis.

In the Korean respondents, $63.5 \%$ were male and $46.5 \%$ were female. Most respondents $(69.2 \%)$ were 21 to 29 years of age. Most respondents $(58.6 \%)$ reported monthly disposable income at 200,000 won to 400,000 won. Approximately 50\% of respondents reported monthly expenses for clothing at fewer than 100,000 won and $42.9 \%$ reported it between 100,000 won and 200,000 won. In Chinese respondents, $59.2 \%$ of respondents were female and $40.8 \%$ of respondents were male. A total of $53.8 \%$ were 17 to 20 years of age and $46.2 \%$ were 21 to 29 years of age. Most respondents (59.2\%) reported a monthly disposable income of 200,000 won to 400,000 won. Approximately $43 \%$ of the respondents reported monthly expenses for clothing at less than 100,000 won.

\section{Results and Discussion}

\section{Factor Analysis for Apparel Shopping Values}

Factor analysis resulted in two factors of apparel shopping values. These were labeled hedonic shopping value $(\alpha=.83)$ and utilitarian shopping value $(\alpha=$ .61 ). The total percent of variance for the two factors was $51.73 \%$ (Table 1). The hedonic shopping value factor reflects the recreational shopping activities of respondents, shopping enjoyment, and enjoyment from apparel shopping. The utilitarian shopping value factor was the tendency of respondents to purchase apparel with care and efficiency to meet consumption desires. Two factors seem to be similar to the hedonic shopping factors and utilitarian shopping factors found by Babin et al. (1994).

\section{Factor Analysis for Apparel Store Attributes}

Factor analysis resulted in five factors of apparel

Table 1. Factors of apparel shopping values

\begin{tabular}{l|c|c}
\hline \multicolumn{1}{c|}{ Factor labels and statements } & Factor loading & $\begin{array}{c}\text { Eigenvalue } \\
\text { Percent of variance } \\
\text { Percent of cumulative variance }\end{array}$ \\
\hline Hedonic shopping value & .80 & 3.93 \\
Clothing shopping is the way I like to spend my leisure time. & .79 & 35.80 \\
Clothing shopping is entertaining. & .73 & 35.80 \\
Clothing shopping excites me. & .68 & .67 \\
I am fond of looking at new products in the mall. & .67 & 1.75 \\
Shopping is exciting. & & 15.93 \\
I can let go of my troubles when I am shopping. & .69 & .83 \\
\hline Utilitarian shopping value & .62 & .61 \\
I buy clothes that I just want. & .58 & .56 \\
I make a plan before I shop. & .55 & \\
I just shop only when I need something necessary. & & \\
I accomplish the planed purpose when I shop. & & \\
I just usually go back home when the clothes I want to buy are & & \\
not available. &
\end{tabular}


store attributes. These were labeled store atmosphere $(\alpha=.74)$, store service $(\alpha=.70)$, selection of goods $(\alpha=$ $.68)$, convenience $(\alpha=.62)$, and salesperson $(\alpha=.64)$. The total percent of variance accounted by these five factors was $65.75 \%$ (Table 2).

Store atmosphere attributes relates to store layout and music. Store services relates to easy return, refund, and repair. Selection of goods reflects product selection and product variety. Items of convenience relate to community involvement and transportation. Items of salesperson attributes relates to the positive attitude of salespersons.

\section{Apparel Shopping Value Segments of Korean and Chinese Consumers}

Four apparel shopping value segments were identified as a result of a cluster analysis (hedonic shopping segment, low involvement shopping segment, high involvement shopping segment, and utilitarian shopping segment). Hedonic shopping was one the largest of the four segments and consisted of 147 respondents (29.2\% of the total). Compared to the other three segments, this one yielded higher scores on the hedonic shopping value than the low involvement shopping segment and the utilitarian shopping segment, but the lowest scores on the utilitarian shopping value. As compared with the other three segments, respondents in the low involvement shopping segment ( $n=94,18.7 \%$ of the total) scored the lowest on the hedonic shopping value and the utilitarian shopping value. Respondents in the high involvement shopping segment ( $n=118,23.4 \%$ of the total) scored the highest in the hedonic shopping value and utilitarian shopping value. Representing 28.8\% ( $n=145)$ of respondents, those in the utilitarian shopping segment scored the highest for utilitarian shopping values, but lower than the hedonic shopping and the

Table 2. Factors of apparel store attributes

\begin{tabular}{|c|c|c|c|}
\hline Factor labels and statements & Factor loading & $\begin{array}{c}\text { Eigenvalue } \\
\text { Percent of variance } \\
\text { Percent of cumulative variance }\end{array}$ & Cronbach's $\alpha$ \\
\hline \multicolumn{4}{|l|}{ Store atmosphere } \\
\hline The store has a good layout. & .80 & 3.99 & .74 \\
\hline The music fits the layout in the store. & .74 & 28.52 & \\
\hline The color goes with the store atmosphere. & .72 & 28.52 & \\
\hline The store atmosphere is to my liking. & .53 & & \\
\hline \multicolumn{4}{|l|}{ Store service } \\
\hline Refunds are available from the store. & .86 & 1.69 & .70 \\
\hline An exchange of the product is available. & .82 & 12.07 & \\
\hline Product servicing is available. & .52 & 40.59 & \\
\hline \multicolumn{4}{|l|}{ Selection of goods } \\
\hline The store has a diversity of product selection. & .83 & 1.23 & .68 \\
\hline \multirow[t]{2}{*}{ The store sells various colors of apparel. } & .79 & 8.84 & \\
\hline & & 49.43 & \\
\hline \multicolumn{4}{|l|}{ Convenience } \\
\hline The store is close to my home. & .80 & 1.21 & .62 \\
\hline The store is close to my favorite stamping ground. & .77 & 8.64 & \\
\hline The store is easily accessible. & .56 & 58.08 & \\
\hline \multicolumn{4}{|l|}{ Salesperson } \\
\hline The salespersons at the store are friendly. & .86 & 1.07 & .64 \\
\hline \multirow[t]{2}{*}{ The salespersons of the store make me feel comfortable. } & .81 & 7.67 & \\
\hline & & 65.75 & \\
\hline
\end{tabular}


high involvement shopping segments for the hedonic shopping values (Table 3 ).

Chi-square tests indicated significant differences between the demographics of Korean and Chinese participants (Table 4). In the hedonic shopping segment, sex $\left(x^{2}=17.30, p<.001\right)$, and monthly expenses for the apparel $\left(x^{2}=7.69, p<.05\right)$ were significantly different between Korean and Chinese respondents. The Korean hedonic segment was almost evenly divided between male $(53.7 \%)$ and female $(46.3 \%)$, but Chinese hedonic segment consisted of more females $(80.0 \%)$ than males $(20.0 \%)$. Only $7.3 \%$ of the Korean hedonic segment spent over 200,000 won on apparel shopping per month but the Chinese hedonic segment was $23.1 \%$ of the total. In low involvement shopping segment, sex $\left(x^{2}=13.20, p<.001\right)$, and monthly expenses for apparel $\left(x^{2}=6.27, p<.05\right)$ were significantly different between Koreans and Chinese. Korean respondents consisted of more male (77.8\%) and more old compared with Chinese. A large number (60.0\%) of Korean respondents spent below 100,000 won on average per month and only $6.7 \%$ spent over 200,000 won on shopping apparel. In the case of Chinese respondents, approximately $77 \%$ spent below 200,000 won and $22.4 \%$ spent over 200,000 won on apparel shopping monthly. In the utilitarian shopping segment, sex $\left(x^{2}=16.01, p<.001\right)$ was significantly different between Koreans and Chinese. The Chinese utilitarian shopping segment was divided into males $(53.6 \%)$ and females $(46.4 \%)$ but Korean respondents consisted of more males $(85.2 \%)$ than females (14.8\%).

\section{Differences in the Importance of Apparel Store Attributes according to Shopping Value Segments}

For Korean college students, the ANOVA indicated significant differences in the importance of store atmosphere $(F=3.42, p<.05)$, convenience $(F=3.49, p<.05)$,

Table 3. Consumer segments regarding apparel shopping values

\begin{tabular}{c|c|c|c|c|c}
\hline \hline Factors & $\begin{array}{c}\text { Hedonic } \\
\text { shopping segment } \\
(n=147)\end{array}$ & $\begin{array}{c}\text { Low involvement } \\
\text { shopping segment } \\
(n=94)\end{array}$ & $\begin{array}{c}\text { High involvement } \\
\text { shopping segment } \\
(n=118)\end{array}$ & $\begin{array}{c}\text { Utilitarian } \\
\text { shopping segment } \\
(n=145)\end{array}$ & $F$ \\
\hline Hedonic shopping values & $.58^{\mathrm{B}}$ & $-1.08^{\mathrm{D}}$ & $.94^{\mathrm{A}}$ & $-.66^{\mathrm{C}}$ & $323.53^{* * *}$ \\
\hline Utilitarian shopping values & $-.85^{\mathrm{B}}$ & $-.77^{\mathrm{B}}$ & $.70^{\mathrm{A}}$ & $.79^{\mathrm{A}}$ & $277.51^{* * *}$ \\
\hline
\end{tabular}

$* * * p<.001$

${ }^{\mathrm{ABC}} \mathrm{A}$ pair of means with the same superscripts indicates significant difference among the groups.

Table 4. Differences between Korean and Chinese segments

$(N=504)$

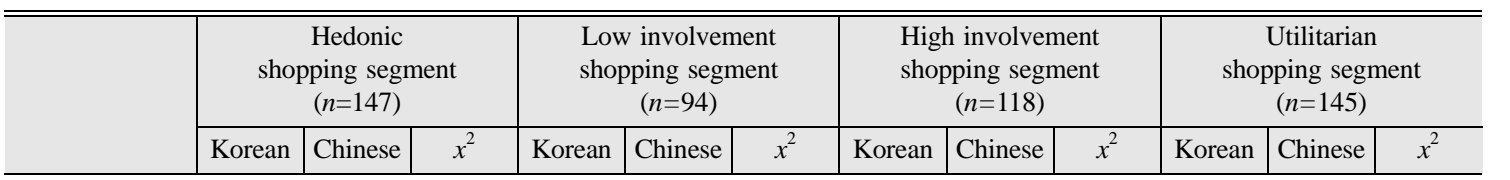

Sex

\begin{tabular}{|c|c|c|c|c|c|c|c|c|c|c|c|c|}
\hline Male & $44(53.7)$ & $13(20.0)$ & \multirow{2}{*}{$17.30 * * *$} & $35(77.8)$ & $20(40.8)$ & \multirow{2}{*}{$13.20 * * *$} & $38(48.7)$ & $19(47.5)$ & \multirow{2}{*}{.01} & $52(85.2)$ & $45(53.6)$ & \multirow{2}{*}{$16.01 * * *$} \\
\hline Female & $38(46.3)$ & $52(80.0)$ & & $10(22.3)$ & $29(59.2)$ & & $40(51.3)$ & $21(52.5)$ & & $9(14.8)$ & $39(46.4)$ & \\
\hline \multicolumn{13}{|c|}{ Monthly expenses for apparel } \\
\hline $\begin{array}{l}\text { Below } \\
100,000 \text { Won }\end{array}$ & $40(48.8)$ & $29(44.6)$ & \multirow{3}{*}{$7.69^{*}$} & $27(60.0)$ & $19(38.8)$ & \multirow{3}{*}{$6.27 *$} & $32(41.0)$ & $13(32.5)$ & \multirow{3}{*}{4.49} & $32(52.5)$ & $42(50.0)$ & \multirow{3}{*}{.74} \\
\hline $\begin{array}{l}100,000- \\
200,000 \text { Won }\end{array}$ & $36(43.9)$ & $21(32.3)$ & & $15(33.3)$ & $19(38.8)$ & & $38(48.7)$ & $17(42.5)$ & & $25(41.0)$ & $33(39.3)$ & \\
\hline $\begin{array}{l}\text { Over } \\
200,000 \text { Won }\end{array}$ & $6(7.3)$ & $15(23.1)$ & & $3(6.7)$ & $11(22.4)$ & & $8(10.3)$ & $10(25.0)$ & & $4(6.6)$ & $9(10.7)$ & \\
\hline
\end{tabular}

$* p<.05, * * * p<.001$ 
and salespersons $(F=2.88, p<.05)$ in terms of apparel store attributes across five segments (Table 5 - a pair of means with the same superscripts indicates a significant difference among the segments). Korean respondents in the high involvement shopping segment considered store atmosphere, convenience, and salespersons to be more important than the other segments, supporting previous studies (Cha et al., 1999; Hwang, 2001; Shim \& Kotsiopulos, 1993). For the Chinese college students, the ANOVA indicated significant differences in the importance of store atmosphere $(F=11.41, \quad p<.001)$, store service $(F=3.49$, $p<.05)$, the selection of goods $(F=3.49, p<.05)$, and convenience $(F=3.49, \quad p<.05)$ across apparel shopping value segments. The hedonic shopping segment considered store atmosphere to be more important as compared with the other three segments. High involvement shoppers were more likely to evaluate store atmosphere, store service, the selection of goods, and convenience as important when compared with the other segments. Chinese college students in the high involvement shopping segment seem to be similar to the results of previous studies (Chang \& Ok, 2007; Lee et al., 2002) in which high involvement Chinese shoppers believed store service, the selection of goods, and convenience more important than the low involvement shopping segment.

\section{Differences in Importance of Apparel Store Attributes between Koreans and Chinese}

\section{1) Apparel Store Attributes between Koreans and Chinese in the Hedonic Shopping Seg- ment}

Differences between Koreans and Chinese in the hedonic shopping segment were significant in the importance of service $(t=3.54, p<.01)$ and convenience $(t=-4.16, p<.001)$ in terms of apparel store attributes. Korean hedonic shoppers evaluated service $(M=3.89)$ as more important than the Chinese respondents $\operatorname{did}(M=3.49)$. On the other hand, a higher percentage of Chinese respondents in the hedonic shopping segment evaluated convenience $(M=3.32)$ to be more important than the Korean respondents did $(M=2.90)$ (Table 6). These differences can reflect the differences in the cultural orientation of respondents. The results are similar to Korean hedonic shoppers that considered store service more important than Chinese consumers did as found by Hong and Kim (2002).

\section{2) Apparel Store Attributes between Koreans and Chinese in the Low Involvement Shop- ping Segment}

In the low involvement shopping segment, significant differences were found between Koreans and Chinese on the importance of three attributes of,

Table 5. Apparel store attributes across shopping value segments

$(N=504)$

\begin{tabular}{|c|c|c|c|c|c|c|c|c|c|c|}
\hline & & \multicolumn{2}{|c|}{$\begin{array}{c}\text { Hedonic } \\
\text { shopping segment } \\
(n=147)\end{array}$} & \multicolumn{2}{|c|}{$\begin{array}{c}\text { Low involvement } \\
\text { shopping segment } \\
(n=94)\end{array}$} & \multicolumn{2}{|c|}{$\begin{array}{c}\text { High involvement } \\
\text { shopping segment } \\
(n=118)\end{array}$} & \multicolumn{2}{|c|}{$\begin{array}{c}\text { Utilitarian } \\
\text { shopping segment } \\
(n=145)\end{array}$} & \multirow[t]{2}{*}{$F$} \\
\hline & & M & S.D & M & S.D & $\mathrm{M}$ & S.D & $\mathrm{M}$ & S.D & \\
\hline \multirow{2}{*}{$\begin{array}{c}\text { Store } \\
\text { atmosphere }\end{array}$} & Korean & 3.43 & $.62^{\mathrm{AB}}$ & 3.28 & $.59^{\mathrm{C}}$ & 3.53 & $.58^{\mathrm{A}}$ & 3.22 & $.68^{\mathrm{C}}$ & $3.42 *$ \\
\hline & Chinese & 3.48 & $.47^{\mathrm{A}}$ & 2.91 & $.85^{\mathrm{B}}$ & 3.56 & $.68^{\mathrm{A}}$ & 3.07 & $.69^{\mathrm{B}}$ & $11.41 * * *$ \\
\hline \multirow{2}{*}{$\begin{array}{c}\text { Store } \\
\text { service }\end{array}$} & Korean & 3.89 & .69 & 3.86 & .74 & 4.02 & .76 & 3.81 & .72 & 1.00 \\
\hline & Chinese & 3.50 & $.64^{\mathrm{B}}$ & 3.24 & $.71^{\mathrm{B}}$ & 3.78 & $.78^{\mathrm{A}}$ & 3.48 & $.66^{\mathrm{B}}$ & $4.64 * *$ \\
\hline \multirow{2}{*}{$\begin{array}{l}\text { Selection } \\
\text { of goods }\end{array}$} & Korean & 3.74 & .69 & 3.78 & .79 & 3.99 & .63 & 3.80 & .70 & 2.01 \\
\hline & Chinese & 3.65 & $.65^{\mathrm{AB}}$ & 3.17 & $.86^{\mathrm{C}}$ & 3.83 & $.61^{\mathrm{A}}$ & 3.49 & $.59^{\mathrm{B}}$ & $7.85 * * *$ \\
\hline \multirow{2}{*}{ Convenience } & Korean & 2.91 & $.67^{\mathrm{B}}$ & 2.93 & $.70^{\mathrm{B}}$ & 3.24 & $.82^{\mathrm{A}}$ & 2.97 & $.62^{\mathrm{B}}$ & $3.49 *$ \\
\hline & Chinese & 3.32 & $.54^{\mathrm{B}}$ & 2.81 & $.86^{\mathrm{C}}$ & 3.57 & $.75^{\mathrm{A}}$ & 3.18 & $.67^{\mathrm{B}}$ & $9.47 * * *$ \\
\hline \multirow{2}{*}{ Salesperson } & Korean & 4.24 & $.66^{\mathrm{B}}$ & 4.18 & $.75^{\mathrm{B}}$ & 4.47 & $.56^{\mathrm{A}}$ & 4.23 & $.66^{\mathrm{B}}$ & $2.88 *$ \\
\hline & Chinese & 4.13 & .66 & 3.87 & .85 & 4.08 & .71 & 3.94 & .85 & 1.36 \\
\hline
\end{tabular}

$* p<.01, * * p<.01, * * * p<.001$

${ }^{\mathrm{ABC}} \mathrm{A}$ pair of means with the same superscripts indicates significant difference among the groups. 
Table 6. Importance of apparel store attributes between Koreans and Chinese in the hedonic shopping segment $(N=147)$

\begin{tabular}{|c|c|c|c|c|c|}
\hline & \multicolumn{4}{|c|}{ Hedonic shopping segment } & \multirow{3}{*}{$t$} \\
\hline & \multicolumn{2}{|c|}{$\begin{array}{l}\text { Korean } \\
(n=82)\end{array}$} & \multicolumn{2}{|c|}{$\begin{array}{c}\text { Chinese } \\
(n=65)\end{array}$} & \\
\hline & $\mathrm{M}$ & S.D & M & S.D & \\
\hline Store atmosphere & 3.43 & .62 & 3.48 & .47 & -0.5 \\
\hline Store service & 3.89 & .68 & 3.49 & .64 & $3.54 * *$ \\
\hline Selection of goods & 3.74 & .68 & 3.64 & .65 & 0.87 \\
\hline Convenience & 2.90 & .66 & 3.32 & .54 & $-4.16^{* * *}$ \\
\hline Salesperson & 4.23 & .66 & 4.13 & .65 & 0.97 \\
\hline
\end{tabular}

apparel store, store atmosphere ( $p<.05, t=2.49)$, store service $(p<.001, t=4.15)$, and the selection of goods $(p<.01, t=3.53)$. Korean respondents evaluated the store atmosphere $(M=3.28)$, store service $(M=3.85)$, and selection of goods $(M=3.77)$ as more important than the Chinese respondents $\operatorname{did}(M=2.90,3.23$, 3.17) (Table 7). These differences indicate that Korean respondents consider store attributes (such as store service and selection) important even for those who are not highly interested in apparel shopping.

\section{3) Apparel Store Attributes between Koreans and Chinese in the High Involvement Shop- ping Segment}

In the high involvement shopping segment, significant differences were found between Koreans and Chinese on the importance of two attributes of apparel store, convenience $(p<.05, t=-2.11)$, and salesperson $(p<.001, t=3.32)$. Korean respondents in the high involvement shopping segment placed more importance on salespersons $(M=4.47)$ than the Chinese respondents $\operatorname{did}(M=4.07)$. In the high involvement shopping segment, store service $(M=3.56)$ was more important to Chinese respondents than to Korean respondents $(M=3.23)$ (Table 8$)$. These differences can reflect that Chinese consumers prefer an easily accessible store even though they are highly involved in apparel shopping compared to Korean consumers.

\section{4) Apparel Store Attributes between Koreans and Chinese in the Utilitarian Shopping Seg- ment}

The differences between Koreans and Chinese in the utilitarian shopping segment were significant in the importance of service $(p<.01, t=3.54)$, selection of goods ( $p<.001, t=-4.16)$, and salespersons $(p<.001$, $t=3.32)$ in terms of apparel store attributes. Korean respondents in the utilitarian shopping segment evaluated service $(M=3.81)$, selection of goods $(M=3.79)$, and salesperson $(M=4.23)$ as significantly more important than did Chinese respondents $(M=3.48,3.49,3.94)$ (Table 9). These results seem to be similar to the findings of Kim and Kim (2005).

Table 7. Apparel store attributes between Koreans and Chinese in the low involvement shopping segment $(N=94)$

\begin{tabular}{|c|c|c|c|c|c|}
\hline & \multicolumn{4}{|c|}{ Low involvement shopping segment } & \multirow{3}{*}{$t$} \\
\hline & \multicolumn{2}{|c|}{$\begin{array}{l}\text { Korean } \\
(n=45)\end{array}$} & \multicolumn{2}{|c|}{$\begin{array}{c}\text { Chinese } \\
(n=49)\end{array}$} & \\
\hline & M & S.D & M & S.D & \\
\hline Store atmosphere & 3.28 & .58 & 2.90 & .85 & $2.49 *$ \\
\hline Store service & 3.85 & .74 & 3.23 & .70 & $4.15^{* * *}$ \\
\hline Selection of goods & 3.77 & .78 & 3.17 & .86 & $3.53 * *$ \\
\hline Convenience & 2.93 & .69 & 2.81 & .86 & 0.76 \\
\hline Salesperson & 4.17 & .74 & 3.86 & .85 & 1.87 \\
\hline
\end{tabular}


Table 8. Apparel store attributes between Koreans and Chinese in the high involvement shopping segment $(N=118)$

\begin{tabular}{|c|c|c|c|c|c|}
\hline & \multicolumn{4}{|c|}{ High involvement shopping segment } & \multirow{3}{*}{$t$} \\
\hline & \multicolumn{2}{|c|}{$\begin{array}{l}\text { Korean } \\
(n=78)\end{array}$} & \multicolumn{2}{|c|}{$\begin{array}{l}\text { Chinese } \\
(n=40)\end{array}$} & \\
\hline & M & S.D & $\mathrm{M}$ & S.D & \\
\hline Store atmosphere & 3.52 & .57 & 3.55 & .68 & -0.25 \\
\hline Store service & 4.07 & .75 & 3.78 & .77 & 1.57 \\
\hline Selection of goods & 3.99 & .62 & 3.82 & .60 & 1.39 \\
\hline Convenience & 3.23 & .82 & 3.56 & .74 & $-2.11 * *$ \\
\hline Salesperson & 4.47 & .56 & 4.07 & .71 & $3.32^{* * *}$ \\
\hline
\end{tabular}

Table 9. Apparel store attributes between Koreans and Chinese in the utilitarian shopping segment

$(N=145)$

\begin{tabular}{|c|c|c|c|c|c|}
\hline & \multicolumn{4}{|c|}{ Utilitarian shopping segment } & \multirow{3}{*}{$t$} \\
\hline & \multicolumn{2}{|c|}{$\begin{array}{c}\text { Koreans } \\
(n=61)\end{array}$} & \multicolumn{2}{|c|}{$\begin{array}{l}\text { Chinese } \\
(n=84)\end{array}$} & \\
\hline & M & S.D & M & S.D & \\
\hline Store atmosphere & 3.21 & .68 & 3.06 & .69 & 1.28 \\
\hline Store services & 3.81 & .72 & 3.48 & .66 & $2.88^{* * *}$ \\
\hline Selection of goods & 3.79 & .70 & 3.49 & .58 & $2.79 * *$ \\
\hline Convenience & 2.96 & .62 & 3.18 & .67 & -1.96 \\
\hline Salesperson & 4.23 & .66 & 3.94 & .85 & $2.20^{*}$ \\
\hline
\end{tabular}

$* p<.05, * * p<.01$

\section{Conclusions and Recommendations}

The results of this study will assist retailers in developing promotional campaigns. Retailers can consider target marketing specific consumers on the bases of shopping value segments. In this study, Korean college respondents highly involved in apparel shopping considered store atmosphere, convenience, and salespersons more important than the Chinese respondents. The Chinese college students in the high involvement shopping segment evaluated store atmosphere, store service, the selection of goods, and convenience as more important than the Korean segments did. Retailers might emphasize store atmosphere, convenience, and salespersons for a successful apparel business in Korea targeting those who were highly involved in apparel shopping. Meanwhile, retailers might emphasize store atmosphere, store service, the selection of goods, and convenience if they target the Chinese who are highly involved in apparel shopping.

A higher percentage of Korean respondents evalu- ated store service as more important than did the Chinese in the hedonic shopping segment. Chinese respondents were more likely to evaluate convenience to be more important than the Koreans did. Korean respondents evaluated store atmosphere, store service, and the selection of goods as more important than the Chinese respondents did in the low involvement shopping segment. In the high involvement shopping segment, Koreans placed more importance on salespersons than the Chinese did. For the Chinese in the high involvement shopping segment, service was more important than for Koreans. Korean utilitarian shoppers were more likely to evaluate service, the selection of goods, and salespersons to be important than the Chinese did. To satisfy the needs of Korean hedonic shoppers, retailers might emphasize store services such as easy returns, refunds, and repair services. Retailers might also increase store convenience for Chinese hedonic shoppers. Store atmosphere, service, and the selection of goods were more important to low involvement Korean shoppers than to low involvement Chinese shoppers. Therefore, 
retailers might consider these three attributes to boost personal satisfaction. If retailers wish to target high involvement shoppers in Korea, they might consider the positive attitudes of salespersons, but in China they might consider store convenience, such as community involvement and good transportation. To satisfy the needs of Korean utilitarian apparel shoppers, retailers might increase store services, the selection of goods, and the attitude of salespersons.

The sample used in this study was limited to urban college students residing in Beijing and Seoul. Chinese urban consumers have higher household incomes, higher brand-name awareness, and greater recognition of foreign brands than rural consumers (Schmitt, 1997). Therefore, the findings of this paper cannot be generalized to other consumer groups or geographic areas. Continuing research is needed to document the inevitable differences in the age of consumers and residential areas.

\section{References}

Anderson, P. M., \& He, X. (1998). Price influence and age segments of Beijing consumers. Journal of Consumer Marketing, 15(2), 152-169.

Babin, B. J., \& Attaway, J. S. (2000). Atmospheric affect as a tool for creating value and gaining share of customer. Journal of Business Research, 49(2), 91-99.

Babin, B. J., Darden, M. R., \& Griffin, M. (1994). Work and/or fun: Measuring hedonic and utilitarian shopping values. Journal of Consumer Research, 20(4), 644-656.

Blackwell, R. D., Miniard, P. W., \& Engel. J. F. (2006). Consumer behavior (10th ed.). OH: Thomsom Higher Education.

Bloch, P. H., Ridgway, N. M., \& Sherrell, D. L. (1989). Extending the concept of shopping: An investigation of browsing activity. Journal of the Academy of Marketing Science, 17(1), 13-21.

Burgess, S. M., \& Steenkamp, E. M. (1999). Value priorities and consumer behavior in a transitional economiy: The case of South Africa. In R. Batra (Ed.), Marketing issues in transitional economics (pp. 85-105). Norwell: Kluwer Academic Press.

Cha, I. S., Ahn, S. H., \& Lee, K. H. (1999). A study on clothing shopping orientations and store choice criteria on department stores consumers. Journal of the Korean Society of Clothing and Textiles, 23(2), 284-295.

Chang, S. K., \& Ok, K. H. (2007). Store evaluative criteria, clothing evaluative criteria, and purchasing behavior for casual wear according to shopping orientation of Chinese college students. The Research Journal of the Costume Culture, 15(1), 98-112.

China Customs Statistics. (2008). China customs statistics year book 2007. Hong Kong: Asia Economic Information \& Consultancy Limited.

Crowley, A. E., Spangenberg, E. R., \& Hughes, K. R. (1992). Measuring the hedonic and utilitarian dimensions of attitudes toward product categories. Marketing Letters, 3(3), 239-249.

Forney, J. C., Rabolt, N. J., \& Friend, L. A. (1993). Clothing values and country of origin of clothing: A comparison of United States and New Zealand University women. Clothing and Textiles Research Journal, 12(1), 36-42.

Hartman, J. B., \& Samra, Y. M. (2008). Impact of personal values and innovativeness on hedonic and utilitarian aspects of web use: An empirical study among United States teenagers. International Journal of Management, 25(1), 77-198.

Hirschman, E. C., \& Krishnan, S. (1981). Subjective and objective criteria in consumer choice: An examination of retail patronage criteria. The Journal of Consumer Affairs, 15(1), 115-127.

Hsu, H. J., \& Burns, L D. (2002). Clothing evaluative criteria: A cross-national comparison of Taiwanese and United States consumers. Clothing and Textiles Research Journal, 20(4), 246-252.

Hong, B. S., \& Kim, K. S. (2002). The apparel purchasing behaviors of middle-upper class women of 20's 30's in Korea and China. Chung-Ang Journal of Human Ecology, 15, 137-150.

Hong, H., \& Koh, A. (2002). Benefit segment of Korean female apparel market: Importance of store attribute. Clothing and Textiles Research Journal, 20(40), 205214.

Hwang, J. M. (2001). The effects of store images and emotions on impulse buying and perceived shopping values. Unpublished master's thesis, Yonsei University, Seoul.

Kim, S. H., \& Chen-Yu, J. (2005). Discount store patronage: A comparison between South Korea and the United States. Clothing and Textiles Research Journal, 23(3), 165-179.

Kim, S. S., \& Kim, H. S. (2005). Comparison of clothing attitudes and clothing purchase criteria between Korean and Korean-Chinese college female students. The Korean Journal of Community Living Science, 16(3), 57-64.

Lee, O. H., Kim, Y. S., \& Liu, G. L. (2002). A study on consumer characteristics, and clothing buying behavior by clothing involvement of college female students in China. Journal of the Korean Society of Clothing and Textiles, 26(2), 205-215. 
Lim, C. U., \& Pyun, H. S. (2000). Effects of retailer service types on consumers' perceived shopping value and shopping satisfaction. Journal of Consumer Studies, 11(3), 169-192.

Lindquist, J. D. (1974). Meaning of image. Journal of Retailing, 50(4), 29-38.

Park, J. (2006). A comparative study regarding the clothing shopping orientation and purchase behavior of Korean and Chinese consumer. Unpublished master's thesis, Seoul National University, Seoul.

Peter, J. P., \& Olson, J. (2007). Consumer behavior \& marketing stragtegy (8th ed.). NY: McGraw-Hill/Irwin.

Rosenthal, D. A., \& Feldman, S. S. (1992). The nature and stability of ethnic identity in Chinese youth. Journal of Cross-cultural Psychology, 23(2), 214-227.

Schmitt, B. (1997). Who is the Chinese consumers? Segmentation in the people's Republic of China. European Management Journal, 15(2), 191-194.

Schwartz, S. H. (1990). Individualism-collectivism: Critique and proposed refinements. Journal of Cross-Cultural Psychology, 21(20), 139-157.

Shen, D., Dickson, M. A., Lennon, S., Montalto, C., \&
Zhang, L. (2003). Cultural influences on Chinese consumers' intentions to purchase apparel: Test and extension of the Fishbein behavioral intentional model. Clothing and Textiles Research Journal, 21(2), 89-99.

Shim, S., \& Kotsiopulos, A. (1992). Patronage behavior of apparel shopping: Part I. Shopping orientation, store attributes, information sources, and personal characteristics. Clothing \& Textile Research Journal, 10(2), 4857.

Shim, S., \& Kotsiopulos, A. (1993). A typology of apparel shopping orientation segments among female consumers. Clothing \& Textile Research Journal, 12(1), 73-85.

Smith, P. B., \& Schwartz, S. H. (1997). Values. In J. W. Berry, Y. H. Poortonga, \& J. Pandey (Eds.), Handbook of cross-cultural psychology (2nd ed., pp. 77-118). Boston: Allyn and Bacon.

Solomon, M. R. (2008). Consumer behavior: Buying having and being (8th ed.). NJ: Prentice Hall.

Srnka, K. J. (2004). Culture's role in marketers' ethical decision making: An integrated theoretical framework. Academy of Marketing Science Review, 1, 1-32.

\section{요 약}

본 연구에서는 한국과 중국 대학생을 대상으로 의복쇼핑가치 유형을 밝히고 쇼핑가치 유형에 따라 한 국과 중국의 대학생들의 의류점포속성 중요도에 차이가 있는지를 알아보고, 각 세분집단에서 한국과 중 국에 대학생들에 따라 의류점포속성 중요도에 차이가 있는지를 알아보았다. 한국의 경우 고 관여 쇼핑 집 단의 응답자들은 다른 집단들 보다 점포 분위기, 편의성, 판매원의 행동을 더 중요하게 생각하고 있었다. 반면 중국 소비자들의 경우 쾌락적 쇼핑 집단인 다른 집단들 보다 점포 분위기를 더 중요시 여기고 있었 으며 고 관여 쇼핑 집단이 다른 집단들 보다 점포 분위기, 점포 서비스, 제품의 구색과 편의성을 더 중요 하게 생각하고 있었다. 쾌락적 쇼핑 집단에서 한국 응답자들은 중국 응답자들 보다 서비스를 더 중요시 여기고 있었으며 중국의 응답자들은 점포의 편의성 더 한국의 응답자들보다 더 중요하게 생각하고 있었 다. 저 관여 쇼핑 집단에서 한국의 응답자들은 중국의 응답자들보다 점포의 분위기와 서비스, 다양한 상 품의 구색을 갖추고 있는지를 더 중요하게 생각하고 있었다. 고 관여 쇼핑 집단에서 한국의 응답자들은 중국의 응답자들보다 판매원의 행동 부분들을 더 중요하게 생각하고 있었으며 중국의 응답자들은 한국의 응답자들보다 점포의 거리와 같은 편리성 부분을 더 중요하게 생각하고 있었다. 실용 쇼핑 집단에서 한국 의 응답자들이 중국의 응답자들보다 점포의 서비스, 상품구색, 판매원을 더 중요하게 생각하고 있었다. 